\title{
Bør leger bidra til å utjevne sosial ulikhet i helse?
}

\author{
Sammendrag \\ Bakgrunn. Hvorvidt og hvordan helse- \\ tjenesten kan eller skal bidra til \\ å utjevne sosial ulikhet i helse er \\ uavklart. Vi har undersøkt hva norske \\ leger mener deres rolle bør være.
}

Materiale og metode. Et representativt utvalg på 1650 norske leger fikk i 2008 tilsendt spørreskjema om deres hensyntaking til sosioøkonomiske forhold i pasientbehandlingen.

Resultater. 1153 (70\%) svarte. $55 \%$ var enig i påstanden om at leger bør bidra til å utjevne helseforskjeller ved å yte ekstra hjelp til pasienter med lav sosioøkonomisk status. Samtidig oppga de fleste at de sjelden/aldri tar hensyn til sosioøkonomiske forhold, som dårlig økonomi ( $81 \%$ ), lav utdanning ( $80 \%$ ) eller arbeidsledighet ( $85 \%$ ). Noen oppga at de tar hensyn til dårlig nettverk (33\%) eller særlig tyngende omsorgsansvar (43\%). På spørsmål om hvordan legene eventuelt tar hensyn, svarte $71 \%$ at de gir råd, bruker ekstra tid $(69 \%)$ eller setter opp ny avtale (58\%). Fastleger oppga oftere enn andre leger at de tar hensyn til dårlig økonomi (31\% mot 15\%), arbeidsløshet ( $25 \%$ mot $12 \%$ ) eller tyngende omsorgsbehov ( $54 \% \operatorname{mot} 39 \%$ ).

Fortolkning. Likebehandling er en sentral verdi blant legene. Hva likebehandling innebærer i praksis er flertydig, og tilsynelatende inkonsistente svar avdekker behovet for faglig og politisk klargjøring av hvilket likhetsprinsipp som bør styre legers praksis.

\section{Berit Bringedal}

berit.bringedal@legeforeningen.no

Legeforeningens forskningsinstitutt

Postboks 1152 Sentrum

0107 Oslo

\section{Kristine Bærøe}

Senter for vitenskapsteori

Universitetet i Bergen

Det er godt dokumentert at helse og sosioøkonomisk status henger sammen (1-3). Lav sosioøkonomisk status er forbundet med dårligere helse enn høy sosioøkonomisk status når man kontrollerer for andre faktorer.

Denne innsikten har fått stor oppmerksomhet de siste årene. Faglig handler diskusjonen om årsaker til ulikheten, og om hva som er effektive tiltak mot ulikhet. Politisk er spørsmålet hva som kan og bør gjøres. I Norge utarbeidet Helsedirektoratets ekspertgruppe på sosiale ulikheter i helse i 2005 «Handlingsprinsipper for å takle sosial ulikhet $\mathrm{i}$ helse» (4), og denne dannet i sin tur grunnlag for en stortingsmelding om strategier for å utjevne ulikhetene (3).

Forslagene i stortingsmeldingen bygger på at helsetjenestens rolle for å utjevne sosial ulikhet $i$ helse anses som relativt begrenset; idet man mener at de viktigste årsakene til ulikheten ikke skyldes mekanismer som helsetjenesten kan kontrollere (1-5). Faktorer som inntekt, utdanning, jobb, kjønn og etnisk bakgrunn - kort sagt sosioøkonomisk status - har større betydning enn helsetjenester på fordelingen av sykelighet og dødelighet $\mathrm{i}$ befolkningen.

Selv om helsetjenestens rolle er liten, har den trolig en viss innflytelse på fordelingen av sykelighet og dødelighet mellom ulike sosioøkonomiske grupper. Empirisk forskning om sammenhengen mellom sosioøkonomisk status og bruk av helsetjenester, peker i retning av at høyere status betyr økt bruk av helsetjenester $(6,7)$. Med mindre vi antar at helsetjeneste ikke har noen effekt eller har negativ effekt på helsen, kan det dermed se ut til at mønsteret i bruk av helsetjenester forsterker den sosioøkonomiske ulikheten i helse. Loven om den inverse sammenhengen mellom behov for helsetjeneste og bruk av helsetjeneste er ikke avkreftet (8).

I et samfunnsmedisinsk perspektiv er det ukontroversielt å rette spesifikke tiltak mot spesielt utsatte pasientgrupper. Slike tiltak er etablert på bakgrunn av definerte behov, for eksempel tilbud om rusavvenning. Men at legen skulle bidra til utjevning av sosioøkonomiske helseforskjeller gjennom særbehandling av enkeltpasienter som tilhører en bestemt sosioøkonomisk gruppe, er ikke like ukontroversielt. Samia Hurst har argumentert sterkt mot at legen skal ta noen andre hensyn enn de rent medisinske, alt annet ville være i strid med de etablerte etiske normer om at det ikke skal gjøres forskjell på kong Salomo og Jørgen Hattemaker (9). Argumentet til forsvar for å ta hensyn til pasientens sosioøkonomiske situasjon er at ved å forholde seg nøytral bidrar man til å fremme helseulikhet mellom Salomo og Jørgen i kong Salomos favør. Derfor bør legen være særlig oppmerksom på pasientens sosioøkonomiske situasjon for å demme opp eller kompensere for dette $(10,11)$.

I denne undersøkelsen har vi spurt norske leger om de tar hensyn til sosioøkonomiske faktorer i møte med enkeltpasienter, hvordan de eventuelt gjør det og om de mener at leger $b ø r$ ta slike hensyn.

\section{Materiale og metode}

Høsten 2008 spurte vi et representativt utvalg av norske leger om, og eventuelt hvordan, legene faktisk tar - og bør ta - hensyn til sosial ulikhet i pasientbehandlingen. Utvalget tilhører et panel av leger som ble etablert i 1994, og som siden er blitt komplettert to ganger for å sikre representativiteten, det såkalte Referansepanelet. Panelet sammenliknes jevnlig med Legeforeningens medlemsregister med hensyn til fordelingen av spesialiteter, kjønn og alder for å sikre at det er representativt. Dette ble sist gjort i 2008. Spørsmålene om legenes eventuelle ansvar for å redusere sosial ulikhet $\mathrm{i}$ helse utgjorde bare en mindre del av et omfattende spørreskjema. Det ble sendt i post til 1650 personer og purret én gang.

\section{Hovedbudskap}

- Over halvparten av legene mener de bør ta hensyn til sosioøkonomiske faktorer i pasientbehandlingen

- Flertallet av legene oppgir at de ikke tar slike hensyn

- Hvilket likhetsbegrep som legges til grunn, kan bestemme synet på legens rolle 
Spørsmålene var formulert som påstander $i$ tre grupper. Den første dreide seg om hvorvidt kjennskap til ulike sider ved pasientens livssituasjon påvirker måten legen behandler pasienten på. Svaralternativene var aldri, sjelden, ofte, svært ofte. Den andre gruppen av spørsmål dreide seg om hvordan legen behandler pasienten annerledes, dersom kunnskapen om livssituasjon påvirket pasientbehandlingen. Svaralternativene var aldri, sjelden, ofte, svært ofte. Den tredje spørsmålsgruppen var formulert som påstander om legens ansvar og verdier som respondenten kunne si seg helt eller delvis enig eller uenig $i$.

For de to første spørsmålsgruppene tok vi hensyn til at en del av utvalget ikke har pasientkontakt, eller en type kontakt som gjør at spørsmålene ikke er relevante for dem, ved alternativet «Passer ikke for meg» i første spørsmål og et betinget spørsmål i det andre («Sett at du påvirkes av denne kunnskapen, --»). De som svarte at påstanden ikke passet, er ikke tatt med i beregningene. Holdningsspørsmålene i den tredje gruppen syntes vi det var interessant å få alle legenes vurdering av.

Dataene er analysert med SPSS 16.0. I sammenlikningene av hvordan legene svarer, har vi sett spesielt på betydningen av om vedkommende er fastlege eller ikke. Forskjellene er signifikanstestet ved hjelp av khikvadrattesten. Vi sjekket konsistensen i svarene ved hjelp av korrelasjonsmålet gamma. Positiv gamma betyr at positivt svar på den ene variabelen følges av positivt svar på den andre variabelen, mens negativ gamma betyr at positive og negative svar opptrer sammen. Gamma varierer mellom -1 og 1, og jo nærmere 0 , desto svakere er sammenhengen.

\section{Resultater}

Av 1650 utsendte spørreskjemaer ble 1153 $(69,9 \%)$ besvart. Flertallet av respondentene oppga at de sjelden eller aldri tar hensyn til sosioøkonomiske faktorer i pasientbehandlingen. Andelen leger som svarte at kjennskap til en levekårsfaktor sjelden eller aldri får betydning for behandlingen av pasienten, varierte fra $542(57,5 \%$ ) (ansvar for familiemedlemmer med særlig omsorgsbehov) til 897 (94,4\%) (god økonomi) for de ulike levekårsfaktorene (tab 1). En relativt stor andel oppgir at de tar hensyn til om pasienten har særlige omsorgsforpliktelser 401 $(42,5 \%)$ eller dårlig nettverk 319 (33,4 \%).

Dersom sosioøkonomiske faktorer i noen grad tas hensyn til, gjøres det ved å bruke mer tid på pasienten (ny avtale, lengre konsultasjon eller mer rådgivning). I tabell 2 ser vi at det å bruke ekstra tid, sette opp ny avtale og å gi råd er de vanligste måtene legen tar hensyn til levekårsfaktorer på i pasientbehandlingen.

Til spørsmålet om legene $b ø r$ bidra til å utjevne helseforskjeller i befolkningen ved å yte ekstra hjelp til pasienter med lav sosioøkonomisk status, sier 566 (55,3\%) seg helt eller delvis enig i denne påstanden, mens 457 $(44,7 \%)$ sier at de er helt eller delvis uenig. Selv om 996 leger $(95 \%)$ sier seg helt eller delvis enig $i$ at de forventes å yte den samme helsehjelpen til pasienter med lik medisinsk status uavhengig av pasientenes sosioøkonomiske status, oppgir $763(73,4 \%)$ at de samtidig forventes å yte særskilt tilpasset hjelp til pasienter med sosioøkonomiske livsbetingelser under gjennomsnittet (tab 3). Dette samsvarer med at $712(72,1 \%)$ også rapporterer om et sprik mellom forventinger om å yte lik helsehjelp og forventninger om særskilt innsats for sosioøkonomisk vanskeligstilte.

Andelen fastleger som oppgir at de tar hensyn til pasientens sosiale og økonomiske livsbetingelser, er høyere enn for andre leger (tab 4). $154(62,9 \%)$ av fastlegene er helt eller delvis enig i påstanden om at leger bør bidra til å utjevne helseforskjeller i befolkningen, mens $411(53,1 \%)$ av øvrige leger mener dette $(\mathrm{p}=0,007)($ tab 5).

I analyse av holdningsmessig konsistens sjekket vi korrelasjon mellom variabler som målte hvorvidt legene tar hensyn til sosioøkonomiske forhold, og variabler som målte om legene mener det er riktig å ta ikke-medisinske hensyn. $42,5 \%$ av legene oppgir at de tar hensyn til om pasienten har omfattende omsorgsforpliktelser. Svarene på denne variabelen er positivt korrelert med påstanden om at leger bør bidra til å utjevne helseforskjeller i befolkningen ved å yte ekstra hjelp til pasienter med lav sosioøkonomisk status (gamma $=0,277)$, mens den er negativt korrelert med påstanden om at pasienter med lik medisinsk status bør få nøyaktig den samme behandlingen, uavhengig av sosioøkonomiske livsbetingelser (gamma $=-0,482)$.

\section{Diskusjon}

Flertallet av legene oppgir at deres måte å behandle pasientene på ikke påvirkes av kjennskap til pasientens sosioøkonomiske livssituasjon. Dette er konsistent med at 847 $(82,2 \%)$ er helt eller delvis enig i påstanden om at pasienter med lik medisinsk status bør få nøyaktig den samme helsehjelpen, uavhengig av sosioøkonomiske livsbetingelser. Samtidig oppgir $566(55,3 \%)$ at de mener at leger bør bidra til å utjevne helseforskjeller i befolkningen ved å yte ekstra hjelp til pasienter med lav sosioøkonomisk status.

Det kan være flere årsaker til den tilsynelatende inkonsistensen i disse svarene. En mulighet er at flere leger mener de bør yte ekstra hjelp, men at betingelsene for dette

Tabell 1 Antall og prosentandel leger som oppgir at pasientbehandlingen ofte eller svært ofte påvirkes av følgende kunnskap om pasientens livssituasjon. $n=932-954$

\begin{tabular}{|lc} 
& Ofte/svært ofte \\
\hline Ansvar for familiemedlemmer med særlig omsorgsbehov & $401(42,5)$ \\
\hline Dårlig sosialt nettverk & $319(33,4)$ \\
\hline Dårlige boforhold & $209(22,0)$ \\
\hline Mentalt stressende arbeid & $193(20,7)$ \\
\hline Fysisk stressende arbeid & $218(20,3)$ \\
\hline Mangel på eller lav utdanning & $187(19,6)$ \\
\hline Godt sosialt nettverk & $182(19,2)$ \\
\hline Dårlig økonomi & $179(18,8)$ \\
\hline Arbeidsløshet & $140(14,8)$ \\
\hline God økonomi & $53(5,6)$ \\
\hline
\end{tabular}

Tabell 2 «Sett at du påvirkes av kunnskap om pasientens sosioøkonomiske livssituasjon, hvordan behandler du pasienten annerledes?» Antall og prosentandel leger som svarte ofte/svært ofte på svaralternativene. $n=840-900$

\begin{tabular}{lc} 
& Ofte/svært ofte \\
Gir pasienten råd & $636(71,4)$ \\
\hline Bruker ekstra tid & $623(69,2)$ \\
\hline Setter opp ny avtale & $512(57,9)$ \\
\hline Endrer bevisst min oppførsel & $284(31,8)$ \\
\hline Spør om pasienten har råd til medisinen & $209(23,8)$ \\
\hline Tar mindre betalt & $139(16,5)$ \\
\hline Skriver ut/forlenger sykmelding & $141(16,1)$ \\
\hline Lar være å kreve betaling & $106(12,5)$ \\
\hline Anbefaler søknad om medisinsk rehabilitering eller uføretrygd & $94(10,8)$ \\
\hline Forskriver beroligende medikament eller sovemedisin & $16(1,8)$
\end{tabular}


Tabell 3 Antall og prosentandel leger som er helt eller delvis enig i følgende påstander. $n=948-1043$

\begin{tabular}{lc} 
& Antall (\%) \\
$\begin{array}{l}\text { Legene forventes å yte den samme helsehjelpen til pasienter } \\
\text { med lik medisinsk status, uavhengig av deres sosioøkono- } \\
\text { miske livsbetingelser }\end{array}$ & 996 (95,0) \\
$\begin{array}{l}\text { Det er mitt ansvar at alle mine pasienter får de helsetjenes- } \\
\text { tene de trenger }\end{array}$ & $855(83,2)$ \\
\hline $\begin{array}{l}\text { Pasienter med lik medisinsk status bør få nøyaktig den } \\
\text { samme behandlingen, uavhengig av sosioøkonomiske livsbe- }\end{array}$ & $847(82,2)$ \\
tingelser & $843(82,1)$ \\
\hline $\begin{array}{l}\text { Legene forventes å gi stort rom for pasientenes egne ønsker } \\
\text { om hjelp og oppfølging }\end{array}$ & $763(73,4)$ \\
\hline $\begin{array}{l}\text { Legene forventes å yte særskilt tilpasset hjelp til pasienter } \\
\text { med sosioøkonomiske livsbetingelser under gjennomsnittet }\end{array}$ & $712(72,1)$ \\
\hline $\begin{array}{l}\text { Det er et sprik mellom forventninger om å yte lik helsehjelp og } \\
\text { forventninger om målrettet innsats for sosioøkonomisk van- } \\
\text { skeligstilte pasienter }\end{array}$ & $566(55,3)$ \\
\hline $\begin{array}{l}\text { Leger bør bidra til å utjevne helseforskjeller i befolkningen ved } \\
\text { à yte ekstra hjelp til pasienter med lav sosioøkonomisk status }\end{array}$ & $305(30,5)$ \\
\hline $\begin{array}{l}\text { Jeg må ofte gå på akkord med egne verdier for å møte de } \\
\text { samfunnsmessige forventningene }\end{array}$ &
\end{tabular}

ikke er (tilstrekkelig) til stede. Slike betingelser kan være av ressursmessig art, som tid, kompetanse, tilgjengelig kunnskap eller refusjonsordninger.

En annen mulig årsak til tilsynelatende inkonsistens kan være ulik tolking av påstandene som de blir bedt om å ta stilling til. Hva som ligger i å yte «ekstra hjelp» til pasienter med lav sosioøkonomisk status, er ikke ty-

delig presisert i spørreskjemaet, på samme måte som «lik medisinsk status» er åpent for tolkinger. Dersom faktorer som ligger utenfor strengt medisinske (biologiske) forhold, antas å påvirke pasientens helse/resultatet av behandlingen, er det grunn til å anta at fortolkningen av «medisinsk status» gjerne også inkluderer sosioøkonomiske faktorer. I så måte vil pasienter med lav sosioøkono-
Tabell 4 Antall og prosentandel fastleger $(n=232-245)$ og andre leger $(n=600-708)$ som svarer «ofte» eller «svært ofte» på spørsmål om og eventuelt hvordan de tar hensyn til kunnskap om pasientens livssituasjon i behandlingen

\begin{tabular}{lccc} 
& Fastleger & Andre leger & P-verdi \\
\hline Dårlig økonomi & $76(31,1)$ & $103(14,6)$ & $<0,001$ \\
\hline God økonomi & $21(8,6)$ & $32(4,5)$ & 0,023 \\
\hline Mangel på eller lav utdanning & $65(26,5)$ & $122(17,3)$ & 0,002 \\
\hline Arbeidsløshet & $60(24,5)$ & $80(11,5)$ & $<0,001$ \\
\hline Mentalt stressende arbeid & $76(31,5)$ & $117(17,0)$ & $<0,001$ \\
\hline Fysisk stressende arbeid & $86(35,4)$ & $132(19,1)$ & $<0,001$ \\
\hline Dårlig sosialt nettverk & $99(40,6)$ & $220(31,1)$ & 0,007 \\
\hline Godt sosialt nettverk & $49(20,2)$ & $133(18,9)$ & 0,706 \\
\hline Dårlige boforhold & $55(22,4)$ & $154(21,8)$ & 0,858 \\
\hline Ansvar for familiemedlemmer med særlig omsorgsbehov & $133(54,4)$ & $268(38,5)$ & $<0,001$ \\
\hline Bruker ekstra tid & $187(79,6)$ & $435(65,7)$ & $<0,001$ \\
\hline Gir pasienten råd & $193(82,1)$ & $441(67,5)$ & $<0,001$ \\
\hline Setter opp ny avtale & $189(80,4)$ & $322(49,8)$ & $<0,001$ \\
\hline Skriver ut beroligende medikament eller sovemedisin & $10(4,3)$ & $6(0,9)$ & 0,001 \\
\hline Skriver ut/forlenger sykmelding & $79(34,1)$ & $62(9,7)$ & $<0,001$ \\
\hline Anbefaler søknad om medisinsk rehabilitering & & & \\
eller uføretrygd & $41(17,7)$ & $53(8,3)$ & $<0,001$ \\
\hline Spør om pasienten har råd til medisinen & $72(30,4)$ & $136(21,4)$ & 0,005 \\
\hline Lar være å kreve betaling & $43(18,1)$ & $63(10,3)$ & 0,002 \\
\hline Tar mindre betalt & $68(28,7)$ & $71(11,8)$ & $<0,001$ \\
\hline Endrer bevisst min oppførsel & $84(35,9)$ & $200(30,5)$ & 0,127 \\
\hline & & & 0.127 \\
\hline
\end{tabular}

misk status fremstå med et annet medisinsk behov enn pasienter med høyere sosioøkonomiske livsbetingelser, til tross for at den medisinske (biologiske) statusen i utgangspunktet vil være lik.

En tredje mulig forklaring på tilsynelatende inkonsistens er selvsagt at spørsmålsformuleringene var uklare. Ved å se på korrelasjonen mellom svar som skulle høre sammen, fikk vi en sjekk på om svarene tydet på holdningsmessig konsistens. Korrelasjonen mellom hvorvidt legene tok hensyn til tyngende omsorgsansvar og hvorvidt de mener det er riktig å ta hensyn til lav sosioøkonomisk status var svakt positiv. Positiv korrelasjon betyr at det er en tendens til at den som svarer «ofte» på spørsmålet om omsorgsansvar, samtidig er enig i at legen bør yte ekstra hjelp til pasienter med lav sosioøkonmomisk status, altså å ta hensyn til ikke-medisinske forhold. Fordi korrelasjonen er svak, betyr det også at mange svarer positivt på omsorgsansvar, men er uenig $\mathrm{i}$ at de bør ta slike hensyn.

Korrelasjonen mellom holdning til påstanden om at legen tar hensyn til om pasienten har særlig omsorgsforpliktelser og påstanden om at pasienter med lik medisinsk status bør få nøyaktig den samme behandlingen uavhengig av sosioøkonomiske livsbetingelser er sterkere, og negativ (gamma = $-0,482$ ). Det betyr at å ta hensyn til tyngende omsorgsansvar ofte opptrer sammen med å være uenig i at man ikke bør ta hensyn til sosioøkonomiske livsbetingelser i pasientbehandlingen, altså holdningsmessig konsistens.

\section{Hva innebærer likhet i helsetjenesten?}

Et sentralt prinsipp i velferdsstaten er likebehandling. I Etiske regler for leger heter det: «En lege må ikke på noen måte søke å skaffe enkeltpasienter eller grupper en uberettiget økonomisk, prioriteringsmessig eller annen fordel» (12).

Gitt det vi vet om sosialt betinget helseulikhet, er et springende punkt hva som utgjør en uberettiget fordel. «Berettiget» eller «uberettiget» i denne sammenheng er tett knyttet til politiske spørsmål om rettferdig fordeling av fellesskapets ressurser i en offentlig finansiert helsetjeneste: Er det rettferdig å la sosiale og økonomiske forhold rettferdiggjøre ulik behandling av pasienter med ellers lik klinisk status?

Skillet mellom innsatslikhet og resultatlikhet kan illustrere forskjellen på to posisjoner her. At like tilfeller behandles likt, kan bety at to pasienter med samme diagnose skal ha samme behandling - eller samme mengde ressurser - eller samme prioritet. Dette likhetsprinsippet kalles innsatslikhet. Alternativt kan likhet defineres i forhold til resultatet av behandlingen. I det tilfellet må innsatsen ofte være ulik, for å realisere et likt resultat. Dersom sosioøkonomiske forhold tilsier at en pasient trenger mer ressurser for å oppnå samme behandlingseffekt, vil målet 
Tabell 5 Antall og prosentandel fastleger ( $n=237-246)$ og andre leger $(n=747-797)$ som er helt eller delvis enig i noen påstander om legers ansvar
Jeg må ofte gå på akkord med egne verdier for å møte de

samfunnsmessige forventningene

\section{Fastleger}

Andre leger

P-verdi

Leger bør bidra til å utjevne helseforskjeller i befolknin-

gen ved å yte ekstra hjelp til pasienter med lav sosioøkonomisk status

Legene forventes å gi stort rom for pasientenes egne ønsker om hjelp og oppfølging

$103(42,4) \quad 202(26,8) \quad<0,001$

$209(85,3) \quad 630(81,1) \quad 0,133$

Legene forventes å yte særskilt tilpasset hjelp til pasienter med sosioøkonomiske livsbetingelser under gjennomsnittet

Det er et sprik mellom forventninger om å yte lik helse-

hjelp og forventninger om målrettet innsats for sosioøkonomisk vanskeligstilte pasienter

Pasienter med lik medisinsk status bør få nøyaktig den samme behandlingen, uavhengig av sosioøkonomiske livsbetingelser

Det er mitt ansvar at alle mine pasienter får de helsetjenestene de trenger

Legene forventes å yte den samme helsehjelpen til pasienter med lik medisinsk status, uavhengig av deres sosioøkonomiske livsbetingelser prinsipielle spørsmålet om leger $b ø r$ bidra til å utjevne helseforskjeller i befolkningen ved å yte ekstra hjelp til pasienter med lav sosioøkonomisk status. Hvorvidt legenes innsats vil kunne bidra til større helselikhet i befolkningen, vil være avhengig av flere forhold, særlig hvilken kunnskap man har om effekter, hvilke virkemidler legene har til rådighet og hvor koordinert innsatsen vil være. Som et første steg synes det imidlertid påkrevd med en faglig og politisk avklaring av hvilket likhetsbegrep som bør legges til grunn for legenes praksis.

Oppgitte interessekonflikter: Ingen

\section{Litteratur}

1. Marmot M. The Status Syndrome. How social standing affects our health and longevity. New York: Times Books, 2004

2. CSDH. Closing the gap in a generation: health equity through action on the social determinants of health. Final Report of the Commission on Social Determinants of Health. Genève: World Health Organisation, 2008.

3. St.meld. 20 (2006-2007). Nasjonal strategi for å utjevne sosiale helseforskjeller.

4. Handlingsprinsipper for å takle sosial ulikhet i helse. Oslo: Helsedirektoratet, 2008.

5. Evans RG, M Barer, Marmor TR. Why are some people healthy and others not? The determinants of health of populations. New York: Aldine de Gruyter, 1994

om innsatslikhet ikke tillate en slik forskjellsbehandling, mens målet om resultatlikhet vil innebære forskjellsbehandling. Legenes delte syn på om de bør bidra til å utjevne helseforskjeller i befolkningen ved å yte ekstra hjelp til pasienter med lav sosioøkonomisk status, kan skyldes ulik vektlegging av innsatslikhet versus resultatlikhet $\mathrm{i}$ forståelsen av hva en berettiget prioriteringsmessig fordel innebærer.

Vi har sett at fastleger er mer positive enn andre leger til å ta hensyn til pasientens sosiale og økonomiske livsbetingelser i pasientbehandlingen, i tillegg til «rent» medisinske forhold. Ulikt jobbinnhold og tettere relasjon til pasienten fremstår som rimelige forklaringer på forskjellene som fremgår mellom fastleger og andre leger når det gjelder både erfaringer med og vurderinger av denne tematikken.

Spørsmålet om hvordan helsetjenesten kan bidra til å forsterke eller redusere den sosiale gradienten $\mathrm{i}$ helse, består av flere forhold enn det vi har sett på i denne undersøkelsen. Økonomiske, juridiske og organisatoriske forhold som ligger utenfor den enkelte legens kontroll, kan ha større betydning for legers praksis enn deres vurderinger av hva de kan og bør gjøre innenfor de rammer de kontrollerer - og dermed også om den sosiale ulikheten reduseres eller forsterkes som resultat av helsetjenestens virkemåte.

\section{Konklusjon}

I daglige pasientmøter blir mange leger vel kjent med at sosioøkonomiske forhold virker inn både på sykdomsrisiko og på prognose. Om, og eventuelt hvordan, denne kunnskapen bør virke/virker inn på pasientbehandlingen, er derimot uklart. Resultatene i denne undersøkelsen viser at leger flest oppgir at de tillegger dette relativt liten vekt $i$ sin egen praksis. Imidlertid viser undersøkelsen også at legene deler seg $\mathrm{i}$ to fraksjoner når det gjelder det
6. Grasdal A, Monstad K. Sosial ulikhet i fordelingen av helsetjenester, målemetoder og empiriske funn. I: Haug K, Kaarbøe O, Olsen T. Et helsevesen uten grenser? Oslo: Cappelen Akademisk Forlag. 2009

7. Jensen A. Sosiale ulikheter i bruk av helsetjenester. En analyse fra Statistisk sentralbyrås levekårsundersøkelse om helse, omsorg og sosial kontakt. SSB rapport 2009/6. Oslo: Statistisk sentralbyrå, 2009.

8. Hart JT. The inverse care law. Lancet 1971; 1: 405-12.

9. Hurst SA. Just care: should doctors give priority to patients of low socioeconomic status? J Med Ethics 2009; 35: 7-11.

10. Smeeth $L$, Heath I. Tackling health inequalities in primary care. BMJ 1999: 318: 1020-1.

11. Brekke M. Sosial ulikhet - angår det allmennlegen? Utposten 2003; nr 2

12. Etiske regler for leger. www.legeforeningen.no/id/ 485.1 (5.2.2010).

Manuskriptet ble mottatt 15.5. 2009 og godkjent 10.4. 2010. Medisinsk redaktør Siri Lunde. 